\title{
Türkiye'de Katılım Bankalarının Finansal Performansının Analizi
}

Alper KARAVARDAR' - Arif çilEK²

Makale Gönderim Tarihi: 24.05.2019

Makale Kabul Tarihi: 16.03.2020

\section{Öz}

Bu çalıșmanın amacı Türkiye'de faaliyet gösteren katılım bankalarının performanslarını değerlendirmek ve performans sıralamasını belirlemektir. Çalıșmada Türkiye' de faaliyet gösteren 5 katılım bankası 9 finansal oran kullanılarak analiz edilmiștir. Analiz yöntemi olarak çok kriterli karar verme tekniklerinden olan Multi-MOORA (Multi-Objective Optimization on the basis of Ratio Analysis) kullanılmıș, 2016-2018 dönemi analiz edilmiștir. Multi-MOORA oran metodu, referans noktası yaklașımı ve tam çarpım formu yöntemleri kullanılarak performans sonuçlarına ulașılmıștır. Analiz sonucunda en iyi finansal verimliliğe sahip olan katııım bankasının Vakıf Katılım olduğu belirlenmiștir.

Anahtar Kelimeler: Katılım Bankası, Finansal Performans, MOORA Jel Kodları: F65, G2 1

Doçent Doktor, Giresun Üniversitesi, İktisadi ve İdari Bilimler Fakültesi, İșletme Bölümü, akaravardar@yahoo.com, Orcid ID:0000-0001-7330-4038

2 (Sorumlu Yazar), Öğretim Görevlisi, Giresun Üniversitesi, Bulancak Kadir Karabaș Uygulamalı Bilimler Yüksekokulu, Uluslararası Ticaret Bölümü, arifcilek86@gmail.com, Orcid ID: 00000002-9277-3953 


\section{Analysis of The Fınancial Performance of Participation Bank In Turkey}

\section{Abstract}

The aim of this study is appraise financial performance and determine rank of banks which operates in Participation Banks sector in Turkey. In this study, 5 Participation Bank in Turkey Banks sector is analyzed using 9 financial ratio. Multi-MOORA, which is one of the multi-criteria decision making techniques, was used as the analysis method and 2016-2018 period was analyzed. MOORA ratio method, referance point approach and full multiplication methods used to reach the conclusions of MOORA method. As a result of the analysis, it is determined that the Participation Banks having the best financial performance is Vakıf Participation.

Keywords: Participation Bank, Financial Performance, MOORA Jel Codes: F65, G21

\section{Giriș}

"Bankacılık yasaları ve ilkeleri ile tam rekabet koșulları ve serbest piyasa ekonomisi çerçevesinde anılan bankaların menfaat ve haklarını savunmak, bankacılık sisteminin sağlıklı bir șekilde büyümesi ve çalıșması ile mesleğin gelișmesi, rekabet gücü ve ortamının olușturulması aynı zamanda haksız rekabetin önüne geçmek amacıyla ihtiyaç duyulan kararların alınmasını sağlamak, uygulamak ve uygulanmasını talep etmek için 1/11/2005 tarihli 5411 Sayılı Bankacilık Kanunu ve 28/02/2006 tarih ve 2006/10018 Sayılı Birlik Statüsü ile Türkiye Katılım Bankaları Birliği kurulmuștur" (Türkiye Katılım Bankaları Birliği, 2019). Bu çerçeve de Ülkemizde 2018 yıl sonu itibariyle 5 adet katılım bankası bulunmakta ve faaliyet göstermektedir. 
Tablo 1: Bankacılık Sekłörü İçindeki Katılım Bankalarının Payı

\begin{tabular}{|c|c|c|c|c|c|c|c|}
\hline \multirow{2}{*}{\multicolumn{2}{|c|}{ FiNANSAL BAȘLIKLAR }} & \multicolumn{3}{|c|}{ KATILIM BANKALARI } & \multicolumn{3}{|c|}{ BANKACILIK SEKTÖRÜ } \\
\hline & & \multirow{2}{*}{$\begin{array}{l}\text { Ara. } 18 \\
60.626\end{array}$} & \multirow{2}{*}{$\begin{array}{l}\text { Ara. } 17 \\
57.494\end{array}$} & \multirow{2}{*}{$\begin{array}{c}\begin{array}{c}2018 / \text { Arallik } \\
-2017 \text { (deği- } \\
\text { șim \%) }\end{array} \\
5,4 \%\end{array}$} & \multirow{2}{*}{$\begin{array}{c}\text { Ara. } 18 \\
1.054 .572\end{array}$} & \multirow{2}{*}{$\begin{array}{l}\text { Ara.17 } \\
961.112\end{array}$} & \multirow{2}{*}{$\begin{array}{c}\text { 2018/Aralık } \\
\begin{array}{c}-2017 \text { (değ } \\
\text { șim \%) }\end{array} \\
9,7 \%\end{array}$} \\
\hline \multirow{4}{*}{$\begin{array}{l}\text { TOPLANAN } \\
\text { FONLAR }\end{array}$} & TP & & & & & & \\
\hline & $\begin{array}{l}\text { YP- } \\
\text { DÖviz }\end{array}$ & 67.790 & 43.180 & $57,0 \%$ & 954.893 & 733.817 & $30,1 \%$ \\
\hline & $\begin{array}{l}\text { YP- } \\
\text { MADEN }\end{array}$ & 8.804 & 4.636 & $89,9 \%$ & 41.701 & 24.220 & $72,2 \%$ \\
\hline & TOPLAM & 137.220 & 105.310 & $30,3 \%$ & 2.051 .166 & 1.719 .149 & $19,3 \%$ \\
\hline \multicolumn{2}{|c|}{$\begin{array}{l}\text { KULLANDIRILAN FON- } \\
\text { LAR }\end{array}$} & 124.562 & 106.733 & $16,7 \%$ & 2.465 .582 & 2.145 .479 & $14,9 \%$ \\
\hline \multicolumn{2}{|c|}{$\begin{array}{l}\text { TAKIPTEKI ALACAKLAR } \\
\text { (BRÜT) }\end{array}$} & 5.050 & 3.392 & $48,9 \%$ & 96.611 & 63.990 & $51,0 \%$ \\
\hline \multicolumn{2}{|l|}{ TOPLAM AKTIF } & 206.806 & 160.136 & $29,1 \%$ & 3.867 .135 & 3.257 .819 & $18,7 \%$ \\
\hline \multicolumn{2}{|l|}{ ÖZ VARLIK } & 16.780 & 13.645 & $23,0 \%$ & 421.185 & 359.091 & $17,3 \%$ \\
\hline \multicolumn{2}{|l|}{ NET KÂR } & 2.123 & 1.583 & $34,1 \%$ & 53.522 & 48.648 & $10,0 \%$ \\
\hline \multicolumn{2}{|c|}{ PERSONEL SAYISI } & 15.654 & 15.029 & $4,2 \%$ & 207.716 & 208.280 & $-0,3 \%$ \\
\hline \multirow{3}{*}{ ȘUBE SAYISI } & YURTiçi & 1.120 & 1.029 & $8,8 \%$ & 11.493 & 11.508 & $-0,1 \%$ \\
\hline & YURTDIȘI & 2 & 3 & $-33,3 \%$ & 72 & 77 & $-6,5 \%$ \\
\hline & TOPLAM & 1.122 & 1.032 & $8,7 \%$ & 11.565 & 11.585 & $-0,2 \%$ \\
\hline
\end{tabular}

Kaynak: (Türkiye Katılım Bankaları Birliği, 2019, http://www.tkbb.org.tr/mukayeseli-tablolar, Erișim Tarihi:07.03.2019)

Tablo 1'deki verilere göre Katılım Bankalarının Sektör içindeki payı yaklașı \% 5 civarındadır. Aralık 2018 itibariyle 15.654 kișiye istihdam sağlanmaktadır. Bu sebeple Katılım Bankalarının finansal performanslarının nesnel bir șekilde değerlendirilmesi önem arz etmektedir.

Tüm firmalarda finansal göstergelerin ele alınması suretiyle yapılan performans incelemesinde kullanılan, farklı yaklașıma sahip analiz yöntemleri bulunmaktadır. Öte yandan ekonominin bütünü ve tüm finansal kurumlar için dönem farklılıkları da performans değișikliklerine sebep olabilmektedir (Atukalp, 2019, s. 214).

Bu doğrultuda Çok Kriterli Karar Verme Tekniklerinden (CKKV) biri olan MOORA yöntemi ile Türkiye'de faaliyet gösteren katılım bankalarının finansal performanslarının ölçülmesi hedeflenmiștir.

Çalıșmada bu doğrultuda ilk önce araștırma konusu hakkında literatür incelemesi yapılmıștır. Daha sonra kullanılacak yöntem açıklanmıș, araștırma kapsamındaki katılım bankalarına ilișkin analiz bulguları de- 
ğerlendirilmiș, sonuç kısmında ise çalıșmanın genel değerlendirmesine yer verilmiștir.

\section{Literatür Taraması}

Ülkemizde "Katılım Bankası" adıyla anılan kurum ve kurulușlar dünyada "Islamic Bank" ya da "el-Benkü'l-Isslâmî" olarak tanınırlar. Anılan kurulușların en belirgin özelliği İslam hukuku unsurlarına göre çalıșmaları ve dünya çapında İslam hukuku uzmanlarından olușan danıșma kurullarına sahip olmalarıdır (Aktepe, 2013, s. 17).

Katılım bankaları, faiz almak istemeyen yatırımcıların tasarruflarını bankalara yatırmayan döviz, alıın, arsa, bina vb. șekillerde, murabaha, mudaraba, müșareke, icara, istisna ve selem yöntemleriyle değerlendiren kurulușlardır. Ayrıca yatırımcıların tasarruflarını üretim prosesine girmesi amacı ile inșa edilen ve faaliyetlerini kar-zarar ortaklığı çerçevesinde șekillendiren kurulușlar olarak da bilinir (Takan, 2001, s. 16).

Ülkemiz katılım bankacılığı modeli ile 1980'li yıllarda dıșa açık piyasa ekonomisine geçiș ve küresel piyasalara adapte olma sürecinde tanıșmıștır (Özcan \& Hazıroğlu, 2000, s. 9).

Katılım bankalarının finansal etkinliklerini ölçmeye yönelik birçok çalıșma yapılmıștır. Așağıdaki literatür özetlerinde bankacılık sektöründe Multi-MOORA yöntemi ile yapılan belli bașlı çalıșmalar sıralanmıștır.

Bankaların internet șubeleri uygulamalarının tespit edilen faktörlere göre göre bulanık MOORA tekniği ile değerlendirilerek, mevcut olan veya kazanılacak müșteriler bakımından en uygun internet șubesi uygulamasının tespit edilmesi amaçlanmıș, çalıșma sonucunda analiz kapsamına alınan bankaların internet șubeleri uygulamaları bulanık MOORA tekniğiyle elde edilen değerlere göre sıralanmıș ve sonuçlar tartıșılmıștır (Uygurtürk, 2015).

Türkiye'deki dokuz yabancı sermayeli bankanın etkinliği 2005 2014 yılları arasında operasyonel rekabet gücü derecelendirme notu (OCRA), çok amaçlı optimizasyon oran analizi (MOORA) ve basit katkı ağırlık (SAW) yöntemleri ile ölçülmüștür. Üç yöntemin hepsinde Finans Bank ve Deniz Bank'ın en iyi performansa sahip olduğu ve HSBC bank ve ING Bank'ın onlardan sonra geldiği sonucuna ulașılmıștır (Özbek, 2015). 
2014-2018 dönemleri arasında BIST hisse senetlerinde ișlem gören 10 konvansiyonel bankanın finansal performansları Bulanık AHP ve Bulanık MOORA bütünleșik yaklașımı ile değerlendirilmiștir. Analiz sonuçlarına göre finansal performansın en yüksek olduğu banka Akbank" olurken son sırayı ise "TEB" almıștır. Öte yandan diğer bir ulașılan sonuç ise karlılık oranının finansal performansı pozitif yönde etkilediği olarak tespit edilmiștir. (Șișman \& Doğan, 2016).

BIST'de sigortacılık sektöründe faaliyette bulunan 6 sigorta șirketi 10 adet finansal rasyo çerçevesinde finansal açıdan değerlendirilmiș, MOORA tekniği kullanılarak bazı finansal rasyoların yardımıyla performans sıralaması yapılmıștır (Ömürbek ve Özcan, 2016).

Bulanık MOORA ve Bulanık AHP yöntemleri birleștirilerek 2007. 2016 yılları için Borsa İstanbul'da ișlem gören 12 bankanın finansal performansları değerlendirilmiș, Analiz sonucuna göre finansal performans bakımından ilk sırada "Iș Bankası " son sırada ise "ICBCT" yer almıștır. Ayrıca karlılık oranları, likidite oranları ile sermaye ve bilanço oranları yüksek olan bankanın, finansal performansının da yüksek olabileceği sonucuna ulașılmıștır (Altunöz, 2017).

Bașka bir çalıșmada ise, Borsa İstanbul'da leasing sektöründe 6 finansal kiralama șirketi ve 8 adet finansal oran kullanılmıș, analiz yöntemi olarak, Oran Metodu, Multi-MOORA, Tam Çarpım Formu ve Referans Noktası Yaklașımından faydalanılmıștır (Ceyhan ve Demirci, 2017).

İmalat sektörünün, Ulusal verimlilik istatistik verileri -çalıșan kiși bașına üretim endeksi (2010 Ort.=100)- açısından 2005-2015 yılları arasında en iyi performansı gösterdiği yılın bulunması amaçlanmıștır. İmalat sektöründe en iyi performansın gösterdiği yılın ve en iyi performansı gösteren imalat alt sektörünün bulunmasında da Çok Kriterli Karar Verme (CKKV) yöntemlerinden Multi-MOORA yöntemi kullanılmıștır. Sonuçta; 2015 yılı en iyi performansın gösterildiği dönem olmakla birlikte, bu yıllar arasında da diğer ulașım araçlarının imalatı alt sektörü de en iyi performans gösteren imalat alt sektörü olmuștur (Ömürbek \& Aksoy, 2017).

Borsa İstanbul Banka Endeksinde bulunan mevduat bankalarının finansal performanslarını, 2010-2016 dönemi ele alınarak, ÇKKV tekniklerinden olan Multi-MOORA ile incelemektir. Çalıșmada, ele alınan bankalar için bazı finansal oranlar kriter olarak belirlenerek finansal 
performans analizi yapılmıștır. Analiz sonucunda, Akbank'ın finansal performans bakımından ilk sırada yer aldığı tespit edilmiștir (Atukalp, 2018).

Türkiye'de faaliyet gösteren katılım bankalarının finansal performansları 2016-2017 döneminde çok kriterli karar verme tekniklerinden Multi-MOORA tekniği ile analiz edilmiș, analiz sonucunda Vakıf Katılım Bankası'nın finansal performans açısından ilk sırada yer aldığı sonucuna ulașılmıștır (Erdoğdu, 2018).

Körfez İșbirliği Konseyi (KIK) bölgesindeki İslami bankalar için kurumsal sosyal sorumluluk (KSS) ve finansal performans arasındaki ilișkiyi, örneklenen bankaların yıllık raporlarının açıklanması analizi ile KSS ile ilgili veriler olușturarak incelenmiș, KSS'nin ifșa edilmesi ile İslami bankaların KIK ülkelerindeki finansal performansı arasında anlamlı bir pozitif ilișki olduğunu gözlemlenmiș, ayrıca KSS'nin ifșası ile İslami bankaların gelecekteki finansal performansı arasında pozitif bir ilișki olduğunu göstermektedir, bu da potansiyel olarak İslami bankalar tarafından yürütülen mevcut KSS faaliyetlerinin finansal performansları üzerinde uzun vadeli bir etkisi olabileceğini sonucuna ulașılmıștır (Platonova, Asutay, Dixon, \& Mohammad, 2018).

Körfez İșbirliği Konseyi (KiK) bölgesindeki İslami ve İslami olmayan bankaların, 2007-2009 yıllarında, yani doğal bir stres testini temsil eden 2008 küresel mali krizinde kapsamlı bir örnek kullanılmıș, kurumsal yönetim özellikleri sahiplik yapısının, konsantrasyonunun, yönetim kurulunun büyüklüğü, bileșimi ve bağımsızlığının etkisini ve ülkenin yasal sisteminin ve yatırımcının korunmasının karlılık, verimlilik dahil çok çeșitli banka performans göstergeleri üzerindeki etkisini değerlendirilmiș, 2008 küresel mali krizi sırasında, varlıkların geri dönüșünün ve faaliyet gelirlerinin toplam varlıklarına göre, İslami bankalarda KiK bölgesindeki İslami olmayan bankalara göre sırasıyla yüzde 1 ve 2,5'ten daha yüksek olduğu sonucuna ulașılmıștır ( Chazi, Khallaf, \& Zantout, 2018).

18 farklı ülkede faaliyet gösteren 64 İslami finans kurumunun 2007-2009 yılları arasında maddi olmayan kaynakların, yani entelektüel sermayenin finansal performansı üzerindeki etkilerini deneysel olarak incelenmiș, değișkenler olarak firma büyüklüğü, risk düzeyi ve firma karmașıklığı alınmıș, VAIC yöntemi ile muhasebe performansı ile aktif karlılığı arasında pozitif bir ilișki olduğu, muhasebe performansı ile kullanılan sermaye verimliliği ve beșeri sermaye verimliliği arasında 
anlamlı bir pozitif ilișki olduğunu göstermektedir, ancak yapısal sermaye verimliliği açısından anlamlı bir ilișki yoktur (Nawaz \& Haniffa, 2017).

Bu çerçevede çalıșmada 2016, 2017 ve 2018 yılsonu verileri esas alınarak Ülkemizdeki katılım bankalarının finansal etkinliği Multi-MOORA yöntemi ile ölçülmüștür. Yapılan diğer çalıșmalarda en yakın 2017 yılı verileri üçer aylık olarak analizlere dahil edilmiș olup, 2016-2018 dönemini kapsayan bir çalıșmaya rastlanılamamıștır. Yapılan çalıșmada analizlere dokuz finansal oran dahil edilmiș olup, analiz sonuçlarında yapılan diğer çalıșmalara paralel olarak, finansal performans yönünden birinci ve ikinci sırada Vakıf Katılım ve Kuveył Türk yer alırken, diğer çalıșmalardan farklı olarak üçüncü sırada Ziraat Katılım, dördüncü sırada Albaraka Türk ve son sırada Türkiye Finans yer almaktadır.

\section{Yöntem ve Veri}

Cok kriterli karar verme teknikleri, bu konuda bașvurulabilecek analiz tekniklerindendir. Çalıșmada, Türkiye'de faaliyet gösteren katılım bankalarının finansal performansları, MOORA tekniği kullanılarak analiz edilecektir.

\subsection{Yöntem}

Multi-Objective Optimization on the basis of Ratio Analysis olarak ifade edilen MOORA yöntemi temelinde oran analizine dayalı olmakla birlikte çok hedefli optimizasyon ișlevi gören ve son yıllarda sıklıkla kullanılan ÇKKV yöntemlerindendir (Bravers \& Zavadskas, 2006, s. 445-449).

Bu yöntemi diğer ÇKKV yöntemlerinden ayıran yönleri ve karșılaștırma tablosu așağıda verilmiștir (Bravers \& Zavadskas, 2012, s. 1-25).

Tablo 2: Çok Kriterli Karar Verme Tekniklerinin Performanslarının Karșilaștırılması

\begin{tabular}{|c|c|c|c|c|c|}
\hline $\begin{array}{c}\text { CKKKV } \\
\text { Téknikleri }\end{array}$ & Veri Türü & $\begin{array}{c}\text { Matematiksel } \\
\text { ișlemleri }\end{array}$ & $\begin{array}{c}\text { Hesaplama } \\
\text { Zamanı }\end{array}$ & Güvenilirlik & Basitlik \\
\hline MOORA & Nicel & Minimum & Çok az & lyi & Cok basit \\
\hline AHP & Karıșık & Maksimum & Çok fazla & Zayıf & Çok kritik \\
\hline TOPSIS & Nicel & Orta & Orta & Orta & Çok kritik \\
\hline VIKOR & Nicel & Orta & Az & Orta & Basit \\
\hline ELECTRE & Karıșık & Orta & Fazla & Orta & Orta Kritik \\
\hline PROMETHEE & Karıșık & Orta & Fazla & Orta & Orta Kritik \\
\hline
\end{tabular}


Literatürde MOORA-Oran yöntemi, MOORA-Referans nokta tekniği, MOORA-önem Katsayısı, MOORA-Tam Çarpım Formu, MULTI-MOORA olacak șekilde MOORA yöntemleri olduğu belirtilmektedir (Önay \& Çetin, 2012, s. 90-109). İlgili literatür tarandığında yöntemin genellikle referans noktası yaklașımı ve oran metodu ile kullanıldığı saptanmıș ancak bazı çalıșmalarda ise sadece tek bir yöntemden yararlanıldığı görülmüștür (Önay, 2018, s. 246). Yöntem, alternatiflerin satırları ve kriterlerin sütunları olușturduğu matris șeklinde, verilerin yazılmasıyla bașlar ve așağıdaki gibi devam eder.

Oran metodunda $i=1,2, \ldots, m$ alternatif sayısı $j=1,2, \ldots, n$ kriter sayısı olmak üzere, her bir alternatifin karelerinin toplamının karekökü ile kriterler bölünerek normalizasyon ișlemi yapılır. Bu ișlem,

$$
x_{i j}^{*}=\frac{x_{i j}}{\sqrt{\sum_{i=1}^{m} x_{i j}^{2}}}
$$

formülünden istifade edilerek hesaplanır. $x_{i j}^{*} ; i$. alternatifin, $j$. kıstas için olan değerlerinin normalleștirilmiș değeridir. $x_{i j}^{*} \in[0,1]$ dir. Bazı durumlarda $x_{i j}^{*} \in[-1,1]$ olabilmektedir (Görener, Dinçer, \& Hacıoğlu, 2013, s. 274-293).

Normalize ișlemi tamamlandıktan sonra belirlenen kriterlerin minumum veya maksimum olması durumuna göre ișlemler așağıdaki formülden yararlanılarak hesap edilir. Aslında $j=1,2, \ldots, g$ maksimize edilecek kriterler, $i=g+1, h+2, \ldots, n$ minimize edilecek kriterlerdir (Brauers \& Ginevičius, 2009, s. 121-140).

$$
y_{i}^{*}=\sum_{j=1}^{g} x_{i j}^{*}-\sum_{j=g+1}^{n} x_{i j}^{*}
$$

$y_{i}^{*} ; i$ alternatifin tüm kritere göre normalleștirilmiș değerlendirilmesidir. $y_{i}^{*}$ 'lerin sıralanmasıyla ișlem tamamlanmıș olur (Önay \& Çetin, 2012, s. 90-109).

Referans noktası tekniğinde, oran metodunun yanı sıra, her kıstas için, amaç minimizasyonu minimum noktalar ve amaç maksimizasyon ise maksimum noktaları olan, referans noktaları $\left(r_{j}^{\prime}\right.$ ler) tespit edilen ve tespit edilen noktaların, her $x_{i j}^{*}$ ile olan uzaklıklarının bulunduğu hesaplama șekli olup așağıdaki formülden yararlanılarak çözüme kavușturulan yöntemdir. (Bravers \& Zavadskas, 2006, s. 445-469).

$$
r_{j}-x_{i j}^{*}
$$


Burada;

$i=1,2, \ldots, m$ alternatif sayısını,

$j=1,2, \ldots, n$ kıstasların sayısını,

$x_{i j}^{*}$, i alternatifinin $j$. kıstasların normalleștirilmiș değerini,

$r_{i^{\prime}}$ i. kıstasların referans noktasını ifade etmektedir.

Ortaya çıkarılan matrise, "Tchebycheff Min-Maks Metrik" uygulanır (Brauers \& Ginevičius, 2010, s. 173-209). Bu ișlem,

$$
\min _{i}\left\{\operatorname{maks}_{j}\left(\operatorname{Ir}_{j}-x_{i j}^{*} I\right)\right\}
$$

șeklinde gösterilir. Bu șekilde sıralama yapılarak $\left|r_{j}-x_{i j}^{*}\right|$ mutlak değer kullanılmasına minimizasyon ișleminin $x_{i j}^{*}$ nin $r_{j}^{\prime}$ den büyük olması gibi durumlardan kaynaklı olarak ihtiyaç duyulur (Brauers \& Zavadskas, 2012, s. 1-25).

Ayrıca önem verilen çeșitli sebeplerden kaynaklı olarak bir kriter diğerinden daha az ya da daha fazla önemli olabilir. Bu durumda önem katsayısı alternatifini normalize edilmiș değer ile çarpılarak yani așağıda verilen formülden yararlanılarak hesaplanır (Brauers, Ginevičius, \& Podvezko, 2010, s. 613-640).

$$
\ddot{y}_{i}^{*}=\sum_{j=1}^{g} s_{j} x_{i j}^{*}-\sum_{j=g+1}^{n} s_{j} x_{i j}^{*}
$$

Bu formülde,

$i=1,2, \ldots, g$ maksimize edilecek kriterler,

$i=g+1, g+2, \ldots, n$ minimize edilecek kriterlerdir.

$\ddot{y}_{i}^{*} ; i$. alternatiflerinin önem katsayısıyla tüm kriterlere göre normalleștirilmiș değerlendirmesidir.

$s_{i} ; j$ Kriterinin önem katsayısıdır.

Referans noktası yaklașımında ise önem katsayıları; formül (4) ifadesinde $\left|s_{j} r_{j}-s_{j} x_{j}^{*}\right|$ șeklinde yer alır (Brauers \& Zavadskas, 2012, s. 1-25).

\subsection{Kapsam ve Veri Seti}

Çalıșmada, Türkiye'de faaliyet gösteren katılım bankalarının finansal performansları, 2016-2018 dönemi itibariyle MOORA yöntemi ile incelenecektir. Türkiye' de faaliyet gösteren katılım bankaları Tablo 3 'de yer almaktadır. 
Tablo 3: Türkiye'deki Katılım Bankaları ${ }^{3}$

\begin{tabular}{|l|}
\hline Unvan \\
\hline Albaraka Türk Katııım Bankası A.Ș. \\
\hline Kuveyt Türk Katılım Bankası A.Ș. \\
\hline Türkiye Finans Katııım Bankası A.Ș. \\
\hline Vakıf Katılım Bankası A.Ș. \\
\hline Ziraat Katııım Bankası A.Ș. \\
\hline
\end{tabular}

Söz konusu bankalara ilișkin mali tablo rasyolarına, Türkiye Katılım Bankaları Birliği (TKBB)'nden ulașılmıștır. Buna göre çalıșmada finansal performans değerlendirmesinde Albaraka Türk Katılım Bankası A.Ș. (A1), Kuveył Türk Katılım Bankası A.Ș. (A2), Türkiye Finans Katılım Bankası A.Ș. (A3), Vakıf Katılım Bankası A.Ș. (A4), Ziraat Katılım Bankası A.Ș. (A5) ele alınmıștır.

Çalıșmada katılım bankalarının finansal performans değerlendirmesinde kriter olarak dokuz adet finansal oran ele alınmıștır. Söz konusu oranların belirlenmesinde sektör yapısı ve literatürdeki çalıșmalar dikkate alınmıștır. Bu konuda daha sonra yapılacak çalıșmalarda farklı sermaye yeterliliği, aktif kalitesi, likidite ve karlılık oranları dâhil edilerek incelemede farklılașmaya gidilebilir. Ele alınan söz konusu oranlar Türkiye Katılım Bankaları Birliği (TKBB)'nde yer alan ilgili bankalara ait mali tablo verileri esas alınarak hesaplanmıștır. Oranlar ve formülleri Tablo 4 'de yer almaktadır.

3 Türkiye Emlak Katılım Bankası A.Ș. 2019 yılında kurulduğundan çalıșmaya dahil edilmemiștir. 
Tablo 4: Çalıșmada Kullanılan Oranlar

\begin{tabular}{|l|l|l|l|}
\hline $\begin{array}{l}\text { Finansal } \\
\text { Göstergeler }\end{array}$ & Kod & Oranın Adı & Oranın Formülasyonu \\
\hline \multirow{3}{*}{$\begin{array}{l}\text { Sermaye } \\
\text { Yeterliliği }\end{array}$} & K1 & Sermaye Yeterliliği & $\begin{array}{l}\text { Özkaynaklar / (Kredi + Piyasa + Operas- } \\
\text { yonel Riske Esas Tutar) }\end{array}$ \\
\cline { 2 - 4 } & K2 & $\begin{array}{l}\text { Özkaynakların Aktiflere } \\
\text { Oranı }\end{array}$ & Özkaynaklar / Toplam Aktifler \\
\hline \multirow{3}{*}{ Aktif Kalitesi } & K3 & $\begin{array}{l}\text { Finansal Varlıkların Aktiflere } \\
\text { Oranı }\end{array}$ & Finansal Varlıklar (net) / Toplam Aktifler \\
\cline { 2 - 4 } & K5 & Takipteki Krediler Oranı & $\begin{array}{l}\text { Takipteki Krediler (brüt) / Toplam Krediler } \\
\text { ve Alacaklar }\end{array}$ \\
\cline { 2 - 4 } & K6 & $\begin{array}{l}\text { Likit Aktiflerin Toplam Aktiflere } \\
\text { Oranı }\end{array}$ & Likit Aktifler / Toplam Aktifler \\
\cline { 2 - 4 } & K7 & Cari Oran & Likit Aktifler / Kısa Vadeli Yükümlülükler \\
\hline \multirow{2}{*}{ Likidite } & K8 & Aktif Karlılığı & Net Dönem Karı (Zararı) / Toplam Aktifler \\
\cline { 2 - 4 } & K9 & Özsermaye Karlılığı & Net Dönem Karı (Zararı) / Özkaynaklar \\
\hline \multirow{2}{*}{ Karlılık }
\end{tabular}

Katılım bankalarının finansal performansının değerlendirilmesinde ele alınan kriterlerden ilki sermaye yeterlilik rasyosudur. Sermaye yeterliliği, bankanın finansal sağlamlığının en temel göstergelerinden biridir. Sermaye yeterliliği bankanın sahip olduğu öz kaynakların kredi, piyasa ve operasyonel bileșenlerden olușan risk ağırlıklı varlıklar karșısındaki yeterlilik derecesi konusunda genel bir fikir vermektedir. Bu oran Basel kriterleri kapsamında en az \% 8 olmalıdır. Ancak ülkemizde, BDDK, bankaların finansal sağlamlığını daha üst seviyede tutmak amacıyla bu oranın 12'nin üstünde olmasını istemektedir (Çatıkkaș, Yatbaz, \& Duramaz, 2018, s. 845).

Öz kaynakların aktife oranı, toplam aktiflerin ne kadarının öz kaynaklar tarafından karșılandığını göstermektedir (Ayrıçay, Özçalıcı, \& Bolat, 2017, s. 63)

Finansal varlıkların toplam aktiflere oranı, mevduat dıșı kaynaklardan olușan yani bankalar arası para piyasası ve uluslararası finansal piyasalardan sağlanan kredilerden, varlığa dayalı menkul kıymet ihraçları toplamının toplam aktiflere oranından olușmaktadır. "Bankacılık oran hesaplamalarında net finansal varlıklar, gerçeğe uygun değer farkı kar zarara yansitılan net finansal varlıklar + net satılmaya hazır finansal 
varlıklar + net vadeye kadar elde tutulacak yatırımlar toplamından olușmaktadır" (Ayrıçay, Özçalıcı, \& Bolat, 2017, s. 63).

Kredilerin fonlara oranı, banka bilançosunun aktifinde yer alan toplam kullandırılan fonların, banka bilançosunun pasifinde yer alan toplanan fonların kaç katı olduğunu gösterir. Kredi ve alacakların ne kadarının mevduatlar tarafından finanse edildiğini göstermekte, bir bașka deyișle mevduatın kredi ve alacaklara dönüș oranını vermektedir (Ayrıçay, Özçalıcı, \& Bolat, 2017, s. 63).

Takipteki krediler oranı, tasfiye olacak alacaklar hesabındaki krediler toplamının kullandırılan tüm kredilere oranını gösterir. "Takipteki kredilerin toplam kredilere oranı, bir ekonomide kiși veya kurumların ödeme gücünü, bankalarda da aktif kalitesi ve risk düzeyini gösterir" (Tanınmıș Yücememiș \& Sözer, 2011 , s. 44).

"Likidite, geniș anlamda, ișletme aktiflerinin daha akıșkan, daha kısa vadeli ve daha kolay paraya dönüștürülebilecek șekilde düzenleyerek pasiflerle vade uyumlu hale getiren dengeli bir finansman politikası izlenmesi anlamında kullanılmaktadır" (Ünsal \& Duman, 26-27 Mayıs 2005 , s. 5). Likit aktiflerin toplam aktiflere oranı, toplam aktifler içerisindeki daha kolay ve hızlı nakde dönüștürülebilecek finansal varlıkların payını göstermektedir.

Cari oran bir firmanın dönen varlıkları kısa vadeli borçlarını karșılama gücünü ortaya koymakta olan bir likidite oranıdır. Bir firma için yeterli olup olmaması birtakım etmenlere bağlı olmakla birlikte, cari oranın yüksek olması firmanın borç ödeme gücünün yüksekliğini göstermektedir (Akgüç, 2013, s. 25).

Aktif kârlılığı, varlıklara yapılan toplam yatırımın ne ölçüde net kâr sağladığını; öz kaynak kârlılığı ise ortakları tarafından sağlanan sermayenin ne ölçüde etkin kullanıldığını ortaya koymaktadır. Söz konusu oranların yüksek olması firmanın yatırım kârlılığının yüksek olduğunu göstermektedir (Atukalp, Borsa İstanbul'da İșlem Gören Çimento Firmalarının Finansal Performans Analizi, 2019, s. 214)

\section{Bulgular}

Türkiye'de faaliyet gösteren katılım bankalarının 2016-2018 dönemi ele alınarak, finansal performans analizi için ÇKKV yöntemlerinden MOORA'nın tam çarpım formu, referans noktası ve oran metodundan faydalanılarak Multi-MOORA ile değerlendirme yapılmıștır. Bu çalıșmada yapılan değerlendirme, inceleme dönemine ilișkin verilerin 
aritmetik ortalaması alınarak yapılmıștır. Bu kapsamda Oran metoduna göre analiz sonuçları Tablo 5'de gösterilmektedir.

Tablo 5: Oran Metodu Normalize Edilmiș Karar Matrisi

\begin{tabular}{|c|c|c|c|c|c|c|c|c|c|c|c|}
\hline & K1 & K2 & K3 & K4 & K5 & K6 & K7 & K8 & K9 & & S \\
\hline A1 & 0,409 & 0,371 & 0,469 & 0,417 & 0,681 & 0,471 & 0,430 & 0,260 & 0,314 & 1,522 & 5 \\
\hline A2 & 0,484 & 0,394 & 0,469 & 0,391 & 0,284 & 0,506 & 0,483 & 0,551 & 0,602 & 2,658 & 2 \\
\hline A3 & 0,456 & 0,491 & 0,507 & 0,514 & 0,666 & 0,414 & 0,427 & 0,426 & 0,373 & 1,929 & 4 \\
\hline A4 & 0,518 & 0,463 & 0,480 & 0,415 & 0,083 & 0,498 & 0,544 & 0,477 & 0,486 & 2,839 & 1 \\
\hline A5 & 0,349 & 0,501 & 0,269 & 0,486 & 0,072 & 0,321 & 0,322 & 0,468 & 0,404 & 2,511 & 3 \\
\hline
\end{tabular}

A: Incelenen Bankalar K: Kriterler $\ddot{y}_{i}^{*}$ Değerlendirme S: Sıralama

İlgili finansal oranlara göre yapılan sıralamanın yer aldığı Tablo 6'daki oran metodu sonuçlarına göre, Vakıf Katılım Bankası A.Ș (A4) en yüksek finansal performans değerine sahiptir. Albaraka Türk Katılım Bankası A.Ș. (A1) ise performans sıralamasında oran metoduna göre son sırada yer almaktadır. Vakıf Katılım Bankası A.Ș.'den sonra, finansal verimlilik açısından Kuveył Türk Katııım Bankası A.Ș. (A2) bulunmaktadır.

Diğer bir yaklașım olan referans noktası yaklașımı sonuçları ise Tablo 6.' da verilmiștir.

\section{Tablo 6: Referans Noktası Yaklașımı Matrisi}

\begin{tabular}{|c|c|c|c|c|c|c|c|c|c|c|c|}
\hline & $\mathrm{K} 1$ & $\mathrm{~K} 2$ & $\mathrm{~K} 3$ & $\mathrm{~K} 4$ & $\mathrm{~K} 5$ & $\mathrm{~K} 6$ & $\mathrm{~K} 7$ & $\mathrm{~K} 8$ & $\mathrm{~K} 9$ & & \\
\cline { 2 - 12 } & $\mathrm{mak}$ & $\mathrm{mak}$ & $\mathrm{min}$ & $\mathrm{mak}$ & $\mathrm{min}$ & $\mathrm{mak}$ & $\mathrm{mak}$ & $\mathrm{mak}$ & $\mathrm{mak}$ & & \multirow{3}{*}{$\mathrm{S}$} \\
\cline { 2 - 11 } & 0,518 & 0,501 & 0,269 & 0,514 & 0,072 & 0,506 & 0,544 & 0,551 & 0,602 & & \\
\hline A1 & 0,109 & 0,130 & 0,201 & 0,096 & 0,609 & 0,035 & 0,114 & 0,291 & 0,288 & 0,609 & 5 \\
\hline A2 & 0,034 & 0,107 & 0,200 & 0,123 & 0,212 & 0,000 & 0,060 & 0,000 & 0,000 & 0,212 & 2 \\
\hline A3 & 0,062 & 0,010 & 0,238 & 0,000 & 0,593 & 0,092 & 0,117 & 0,125 & 0,229 & 0,593 & 4 \\
\hline A4 & 0,000 & 0,038 & 0,211 & 0,098 & 0,011 & 0,008 & 0,000 & 0,073 & 0,116 & 0,211 & 1 \\
\hline A5 & 0,169 & 0,000 & 0,000 & 0,027 & 0,000 & 0,184 & 0,221 & 0,083 & 0,198 & 0,221 & 3 \\
\hline
\end{tabular}

$r_{1}$ : Referans Noktası S: Siralama

Tablo 6'ya göre finansal performans bakımından Vakıf Katılım Bankası A.Ș (A4) ilk sırada, Albaraka Türk Katılım Bankası A.Ș. (A1) son sırada yer almaktadır. Bu yaklașımına göre finansal verimlilik açısından ikinci sırada Kuveyt Türk Katılım Bankası A.Ș. (A2) bulunmaktadır. 
Tam çarpım formu sonuçları Tablo 7'de gösterilmiștir. Hesaplama sonucunda ortaya çıkan en büyük değer, finansal verimliliği yüksek olan firmayı göstermektedir.

\section{Tablo 7: Tam Carpım Formu Matrisi}

\begin{tabular}{|c|c|c|c|c|c|c|c|c|c|c|c|}
\hline & $K 1$ & $K 2$ & $K 3$ & $K 4$ & $K 5$ & $K 6$ & $K 7$ & $K 8$ & $K 9$ & $U_{i}=A_{i} / B_{i}$ & $S$ \\
\hline A1 & 15,073 & 7,257 & 15,910 & 94,143 & 5,740 & 27,247 & 41,877 & 0,543 & 7,733 & 540595,64 & 5 \\
\hline A2 & 17,833 & 7,697 & 15,892 & 88,147 & 2,393 & 29,290 & 47,083 & 1,150 & 14,840 & 7486637,02 & 3 \\
\hline A3 & 16,803 & 9,607 & 17,190 & 115,853 & 5,610 & 23,977 & 41,547 & 0,890 & 9,203 & 1582333,82 & 4 \\
\hline A4 & 19,080 & 9,053 & 16,263 & 93,647 & 0,700 & 28,833 & 52,967 & 0,997 & 11,977 & 25903293,87 & 1 \\
\hline A5 & 12,840 & 9,793 & 9,113 & 109,717 & 0,610 & 18,613 & 31,400 & 0,977 & 9,957 & 14105068,87 & 2 \\
\hline
\end{tabular}

$U_{j}=j^{\prime}$ inci alternatifin genel faydası S: Sıralama

Tablo 7'de verilen değerlere göre finansal performans bakımından ilk sırada Vakıf Katılım Bankası A.Ș (A4), ikinci sırada Ziraat Katılım Bankası A.Ș. (A5), son sırada ise Albaraka Türk Katılım Bankası A.Ș. (A1) yer almaktadır.

Oran metodu, referans noktası yaklașımı ve tam çarpım formu birbirinden farklı sonuçlar verebilmektedir. Multi-MOORA tekniğinde, bu üç metodun sonuçları bir arada değerlendirilmekte ve en az ikisinde ortak çıkan sonuç, finansal performans sonucunu göstermektedir. Bu doğrultuda yapılan analiz Tablo 8'da görülmektedir.

\section{Tablo 8: Multi-MOORA Performans Sıralama Sonuçları}

\begin{tabular}{|c|c|c|c|c|}
\hline & Oran & Referans Noktası & Tam Çarpım & Multi-MOORA \\
\hline A1 & 5 & 5 & 5 & 5 \\
\hline A2 & 2 & 2 & 3 & 2 \\
\hline A3 & 4 & 4 & 4 & 4 \\
\hline A4 & 1 & 1 & 1 & 1 \\
\hline A5 & 3 & 3 & 2 & 3 \\
\hline
\end{tabular}

\begin{tabular}{|l|c|}
\hline \multicolumn{2}{|c|}{ Sıralama } \\
\hline Vakıf Katılım & 1 \\
\hline Kuveył Türk & 2 \\
\hline Ziraat Katılım & 3 \\
\hline Türkiye Finans & 4 \\
\hline Albaraka Türk & 5 \\
\hline
\end{tabular}

Tablo 8'de görüldüğü gibi finansal verimlilik bakımından üç yöntemde ilk sırada Vakıf Katılım A.Ș. yer almaktadır. Buna göre Türkiye'de faaliyet gösteren katılım bankalarının 2016-2018 döneminde Vakıf Katılım A.Ș., seçilen kriterlere göre değerlendirme yapıldığında, finansal performans açısından ilk sırada yer almaktadır.

Finansal performans açısından üç yöntemde ikinci sırada çoğunlukla (oran metodu ve referans noktası metodu) Kuveył Türk A.Ș. yer 
almaktadır. Diğer firmalara ilișkin değerlendirme Tablo 8'de görüldüğü gibi, benzer șekilde yapılabilir.

Vakıf Katılım A.Ș.'nin sermaye yeterlilik oranının, likit aktiflerin toplam aktiflere oranının, cari oranının, aktif karlılığının ve öz sermaye karlılığının karșılaștırmalı olarak yüksek olması, takipteki krediler oranının düșük olması ilk sırada yer almasını sağlamıș sağlamıștır. Albaraka Türk Katılım A.Ș.'nin sermaye yeterlilik oranının, öz kaynakların aktiflere oranının, cari oranının ve öz sermaye karlılığının düșük olması, takipteki krediler oranının yüksek olması son sırada yer almasına neden olmuștur.

Illk üç sırada iki kamu sermayeli katılım bankasının yer alması, faaliyet sürelerinin çok uzun olmamasına rağmen, önümüzdeki dönemde katılım bankacılığı sektöründe rekabetin artacağını göstermektedir. Özellikle Ziraat Katılım A.Ș. ve Vakıf Katılım A.Ș’nin konut kredisi fonlama oranlarını sektörün altında sağlaması bunu desteklemektedir. Kuvey† Türk Katılım A.Ș’nin uzun yıllardır katılım bankacılığı sektörünün içinde yer alması, sermaye yeterlilik oranının yüksek olması, likit aktiflerin toplam aktiflere oranının, aktif karlılığının ve öz sermaye karlılığının sektörün en yüksek olması, takipteki krediler oranının düșük olması ikinci sırada yer almasını sağlamıștır.

Dördüncü ve beșinci sırada yer alan Türkiye Finans Katılım A.Ș. ve Albaraka Türk Katılım A.Ș.'nin özellikle takipteki kredilerini tahsil etmesi için özen göstermesi gerekmektedir. Yine aktif karlılıkları ve öz sermaye karlılıkları sektörün altında olduklarından karlılık oranlarını yükseltmeleri için satıșlarını artırmaları gerekmektedir.

\section{Sonuç}

MOORA tekniğinin, oran metodu, referans noktası yaklașımı ve tam çarpım formu olarak sıralanan metotları farklı sonuçlar ortaya koyabilmektedir. Bu sebeple her üç yaklașımın sonuçlarının bir arada değerlendirilerek baskınlık karșılaștırmasının yapılması ve karar verilecek alternatif için en az iki yaklașımın aynı sonucu belirtmesi esasına dayanan Multi-MOORA yaklașımından istifade edilmektedir.

Katılım bankalarının finansal performansı, çalıșmaya dahil edilen finansal oranlar temelinde Multi-MOORA tekniğine göre değerlendirilmiștir. Metotların tamamında ve bu doğrultuda Multi-MOORA değerlendirmesine göre, en iyi finansal performansa sahip olan katılım bankasının Vakıf Katılım Bankası A.Ș. olduğu görülmüștür. Gelecekte Vakıf Katılım Bankası A.Ș’nin katılım bankacılığı sektörüne yön verebileceği, 
sektörün hakim bankası olacağı, rakiplerinin örnek aldığı bir banka olabileceği öngörülebilir.

Vakıf Katılım Bankası A.Ș.'nin sermaye yeterlilik oranı ve cari oran gibi maksimum olması beklenen kriterler bakımından en yüksek değere sahip olması, aktif karlılığının ve öz kaynak karlılığının yüksek değerlere sahip olması, takipteki krediler rasyosu gibi minimum olması beklenen kriterler bakımından ise düșük değer sahip olması, yüksek finansal performans göstermesinde etkilidir. Yeni kurulan bankaların takipteki krediler açısından çok avantajlı olduğu açıktır.

Finansal performans bakımından ilk 3 sırada yer alan Vakıf Katılım Bankası A.Ș., Kuveyt Türk Katılım Bankası A.Ș. ve Ziraat Katılım Bankası A.Ș. ele alındığında sektörde finansal performansı etkileyen ağırlıklı kriterlerin sermaye yeterlilik oranı, cari oran, takipteki krediler oranı, aktif ve özsermaye kârlılığı olduğu gözlemlenmektedir. Bu doğrultuda alanda bundan sonra yapılacak çalıșmalarda ele alınan kriterlerin ağırlıklandırılmasını sayısal bir șekilde ortaya koyan AHP, TOPSIS, VIKOR gibi modellerin de çalıșmaya dahil edilmesi uygun olabilir. Katılım bankacılığının doğmasındaki temel neden, dini inanıșlar nedeniyle konvansiyonel bankacılığa ilgi duymayan tasarruf sahiplerinin yastık altındaki birikimlerini finansal piyasalara dahil etmesidir. Türkiye'de uygulanan katılım bankacılığı modelinde temel olarak Malezya örnek alınmıș alıp, faaliyetlerde dünya uygulamalarına göre dikkat çekici farklar bulunmamaktadır.

Literatürde yer alan, farklı analiz yöntemine sahip çalıșma sonuçları dikkate alındığında, bu çalıșmada nispi olarak yüksek performansa sahip bulunan Vakıf Katılım Bankası A.Ș., Kuveył Türk Katılım Bankası A.Ș. ve Ziraat Katılım Bankası A.Ș. ilgili çalıșmaların bir kısmında yüksek performansa sahip olduğu gözlenmektedir. Kuveył Türk Katılım Bankası'nın takipteki kredi oranını Albaraka Türk Katılım Bankası ve Türkiye Finans Katılım Bankası'na görece düșük tutmuș olması ikinci sıraya yükselmesini desteklemektedir. Çalıșmada Türkiye' de faaliyet gösteren 5 katılım bankası 9 finansal oran kullanılarak finansal bakıș açısıyla analiz edilmiștir.

Bu çalıșmada yapılan değerlendirme, inceleme dönemine ilișkin verilerin ortalaması alınarak yapılmıștır. Türkiye'de faaliyet gösteren katılım bankalarının 2016-2018 dönemi ele alınarak, finansal performans analizi için ÇKKV yöntemlerinden MOORA'nın tam çarpım formu, referans noktası ve oran metodundan faydalanılarak Multi-MOORA ile de- 
ğerlendirme yapılmıștır. Bu çalıșmada yapılan değerlendirme, inceleme dönemine ilișkin verilerin aritmetik ortalaması alınarak yapılmıștır. Her bir yıla ilișkin ayrı birer performans değerlendirmesi yapıldığında farklı sonuçların ortaya çıkabileceği düșünülebilir. Diğer bir ifade ile analizler sonucunda dönemsel olarak performansı yüksek veya düșük olan katılım bankaları yıl bazında ve ayrıca gelecek dönemlerde, farklı performansa sahip olabilirler. Bu doğrultuda yapılacak analizlerde bu durum ele alınabilir.

Katılım bankalarının performanslarına ilișkin yapılan incelemelerde, ele alınan finansal oranların değișmesi farklı sonuçlar ortaya çıkarabilmektedir. Bu da araștırmacılar için değișik bir bakıș açısı yaratmaktadır. Bu noktadan yola çıkarak daha sonra yapılacak çalıșmalarda dönem ve kriter değișikliğine gidilerek veya analiz tekniğinde yapılacak bir değișiklikle, ele alınan firmalara ilișkin performans değerlendirmesine ilișkin farklı bulgulara ulașılabilir. 


\section{KAYNAKÇA}

Akgüç, Ö. (2013). Finansal Yönetim (9. Baskı b.). İstanbul: Avcıoğlu Basım Yayın.

Aktepe, İ. (2013). Sorularla Katılım Bankacılığı (Cilt 4). İstanbul: Türkiye Katılım Bankaları Birliği.

Altunöz, U. (2017). Bankaların Finansal Performanslarının Bulanık MOORA ve Bulanık AHP Yöntemleri Ille Analizi: Türk Bankaları Deneyimi. Route Educational and Social Science Journal, 4(4), 11 6-132.

Atukalp, E. (2018). Bankaların Finansal Performansının Multi-MOORA Yöntemi Ile Analizi. 1. Uluslararası Bankacılık Kongresi (s. 67-78). Ankara: Bașkent Üniversitesi Ticari Bilimler Fakültesi.

Atukalp, E. (2019, Ocak). Borsa İstanbul'da İșlem Gören Çimento Firmalarının Finansal Performans Analizi. Muhasebe ve Finansman Dergisi(81), 214-223.

Ayrıçay, Y., Özçalıcı, M., \& Bolat, I. (2017). Katılım Bankalarının Performanslarının AHP ve GIA Tekniklerinden Olușan Bütünleșik Bir Sistem Ille Değerlendirilmesi: Türkiye Örneği. Pamukkale Journal of Eurasıan Socıoeconomıc Studies, Cilt 4(Sayı 2), 54-69.

Brauers, W. K., \& Zavadskas, E. (2012). Robustness of MULTIMOORA: A Method For Multi-Objective Optimazition. Informatıca, 23(1), 1-25.

Brauers, W., Ginevičius, R., \& Podvezko, V. (2010). Regional Development In Lithuania Considering Multiple Objectives By The Moora Method. Technological and Economic Development of Economy, 16(4), 613-640.

Brauers, W., \& Ginevičius, R. (2009). Robustness In Regional Development Studies. The Case Of Lithuania. Journal Of Business Economics and Maneement, 10(2), 121-140.

Brauers, W., \& Ginevičius, R. (2010). The Economy of The Belgian Regions Tested With MULTIMOORA. Journal of Business Economics and Manegement, 11 (2), 173-209.

Bravers, W., \& Zavadskas, E. (2006). The MOORA Method and Its Application to Privatization in a Transation Economy. Control and Cybernetics, 35(2), 445-469.

Ceyhan, İ., \& Demirci, F. (2017). Multi-MOORA Yöntemi İle Finansal Performans Ölçümü: Leasing Șirketlerinde Bir Uygulama. Bartın Üniversitesi Iktisadi ve İdari Bilimler Fakültesi Dergisi, 8(15), 277-296.

Chazi, A., Khallaf, A., \& Zantout, Z. (2018). Corporate Governance And Bank Performance: Islamic Versus Non-Islamic Banks In GCC Countries. The Journal of Developing Areas, 52(2).

Çatıkkaș, Ö., Yatbaz, A., \& Duramaz, S. (2018). Basel Sermaye Yeterliği Oranındaki Değișimin Türk Bankacılık Sektörü Üzerindeki Etkilerinin İncelenmesi: Katılım Bankaları ve Geleneksel Bankaların Karșılaștırmalı Oran Analizi. İșletme Araștırmaları Dergisi, 10(1), 839-855.

Erdoğdu, A. (2018). Katılım Bankalarının Performans Analizlerine MUlti-MOORA Yöntemille Bir Bakıș. İstanbul Arel Üniversitesi İktisadi ve İdari Bilimler Fakültesi Ekonomi, Yönetim ve Sosyal Araștırmalar Dergisi, 99-111. 
Görener, A., Dinçer, H., \& Hacıoğlu, Ü. (2013). Application of Multi-Objective Optimazation on the Basis Of Ratio Analysis (MOORA) Method for Bank Branch Location Selection. Internatıonal Journal of Finance \& Banking Studies, 2(2), 41-52.

Nawaz, T., \& Haniffa , R. (2017). Determinants of financial performance of Islamic banks: an intellectual capital perspective. Journal of Islamic Accounting and Business Research, 8(2).

Ömürbek, N., \& Aksoy, E. (2017). Ulusal Verimlilik İstatistiklerine Göre İmalat Sektörlerinini Performansının Değerlendirilmesinde Multi-MOORA Yönteminin Uygulanması. Süleyman Demirek Üniveristesi Iktisadi ve Idari Bilimler Fakültesi Dergisi, 22(1), 1-19.

Ömürbek, N., \& Özcan, A. (2016). BiSTıde İșlem Gören Sigorta Șirketlerinin MultiMOORA Yöntemiyle Performans Ölçümü. Uluslararası İșletme, Ekonomi ve Yönetim Perspektifleri Dergisi, 1(2), 64-75.

Önay, O. (2018). Çok Kriterli Karar Verme Yöntemleri (3 b.). Bursa: Dora Yayınları.

Önay, O., \& Çetin, E. (2012). Turistlik Yerlerin Popülaritesinin Belirlenmesi: İstanbul Örneği. İstanbul Üniversitesi İșletme Fakültesi İșletme Ikktisadı Enstitüsü Yönetim Dergisi(72), 90-109.

Özbek, A. (2015). Efficiency Analysis of Foreign Capital Banks in Turkey by OCRA and MOORA. Researh Journal of Finance and Accounting, 6(13), 21-30.

Özcan, M., \& Hazıroğlu, T. (2000). Bankacılıkta Yeni Bir Boyut: Katılım Bankacılığı. Bereket Dergisi, 3(9).

Platonova, E., Asutay, M., Dixon, R., \& Mohammad, S. (2018). The Impact of Corporate Social Responsibility Disclosure on Financial Performance: Evidence from the GCC Islamic Banking Sector. Journal of Business Ethics, 151 (2).

Șișman, B., \& Doğan, M. (2016). Türk Bankalarının Finansal Performanslarının Bulanık AHP ve Bulanık MOORA Yöntemleri İle Değerlendirilmesi. Yönetim ve Ekonimi, 23(2), 353-371.

Takan, M. (2001). Bankacılık Teori Uygulama ve Yönetim. Adana: Nobel Yayınevi.

Tanınmıș Yücememiș, B., \& Sözer, İ. (2011). Bankalardaki Tkipteki Krediler: Türk Bankacılık Sektöründeki Takipteki Kredilerin Tahminine Yönelik Bir Model Uygulaması. Finansal Araștırmalar ve Çalıșmalar Dergisi, Cilt 3(Sayı 5), 43-56.

Türkiye Katılım Bankaları Birliği. (2019, Nisan 22). http://www.tkbb.org.tr/tarihce adresinden alındı

Türkiye Katılım Bankaları Birliği. (2019, http://www.tkbb.org.tr/mukayeseli-tablolar, Erișim Tarihi:07.03.2019, Mart 7). http://www.tkbb.org.tr/mukayeseli-tablolar adresinden alındı

Uygurtürk, H. (2015). Bankaların İnternet Șubelerinin Bulanık MOORA Yöntemi İle Değerlendirilmesi. Uluslararası Yönetim İktisat ve Ișletme Dergisi, 11 (25), 115 -128.

Ünsal, A., \& Duman, S. (26-27 Mayıs 2005). Türkiyedesdeki Bankaların Performanslarının Temel Bileșenler Yaklașımı İle Karșılaștırmalı Analizi. VII. Ulusal Ekonometri ve Istatistik Sempozyumu. İstanbul. 
